UDC $1 / 14$

Davit MOSINYAN

\title{
HISTORY AND MEMORY
}

\begin{abstract}
This paper discusses the issue of the relationship of history and memory. Memory becomes a topic in historical discourses as it deals with identity, especially when we speak of collective memory. The paper presents the history of the relationship of history and memory and suggests a thesis according to which the close interaction between these two concepts can solve the crisis of identity that has been most urgent in our days.
\end{abstract}

Keywords: history, memory, identity, collective memory, narrative, identity crisis.

The reference to the memory in historical discourses is usually perceived as a guarantee of the ontological justification of history since the representative of the past is the memory. Moreover, sometimes these two words appear as synonyms because memory is always the memory of the past, and the past is embodied only in the memory. The so-called legitimacy of the memory began with Herodotus when he had justified his History by saving the events from oblivion.

In recent times, memory has become a wider topic of discussion because it is closely linked to the identity problem, and the latter has been reinterpreted since the $20^{\text {th }}$ century with the global mapping strategies. From this point of view, the memory problem loses its 'impartiality' because the issue gets underlined political tone; the problem of identity implies a political context, especially if it refers to national identity, to collective memory because history is the memory of a nation or any other community. And, consequently, there is a danger of imposing one's own (subjective) memory as history.
Moreover, the possibility of collective memory is often challenged. And if the issue came to the problem of the relationship between a narrative and an event, the political point of view refers to the ability to 'conquer' the memory. For instance, Susan Sontag argues that there is no collective memory, explaining that memory dies with every individual (see Sontag, 2003, p. 85). According to her, collective memory is not a process of recalling, but a set of conditions according to which some events of the past are more important and have taken place in a certain way. From here, it is noticeable that collective memory is bordering with ideology. And since the ideology in Western thought usually is associated with Nazism, chauvinism, racism and other similar concepts, so rebellions against collective memory become clear. If we add psychological considerations that memory is not passive and neutral, but the subject adjusts the past to himself through memory, then it becomes clear that the memory is 'politicized'.

After the discovery that memory was a 'weapon' in history, the contrast between history 
and memory was noticed. One of the first to introduce this contrast and to start the current memory discourse was Maurice Halbawachs.

Through the works of Halbwachs, the idea of a social determination of memory goes like a red thread. At first glance, it may seem that memory is a faculty which could exist only in a person's body or brain, but at least, different remembrances of the same event can be organised within a group and transformed into impersonal or collective memory (see Halbwachs, 1980, p. 50). Moreover, collective memory is not a mechanical sum of individual memories, "it evolves according to its laws, and any individual remembrances that may penetrate are transformed within a totality having no personal consciousness" (Halbwachs, 1980, p. 51). In other words, not only collective memory exists in itself, but it also implies a personal memory because the latter is formed in a particular relationship with a community. Absolutely alone person would not have memory: the need for memory is of social bases. Though no individual memory can be embodied in another person, but every individual experiences the memories of other surrounding individuals, especially if they refer to the common reality for different individuals. As Aleida Assmann writes, "To be part of a collective group such as the nation one has to share and adopt the group's history, which exceeds the boundaries of one's individual lifespan" (Assmann, 2008, p. 52).

After justifying the existence of collective memory, Halbwachs develops the thesis of contradiction between collective memory and history. Preventing the possible reasoning based on his arguments, which would identify the memory and history, Halbwachs writes: "The collective memory is not the same as formal history, and 'historical memory' is a rather unfortunate ex- pression because it connects two terms opposed in more than one aspect" (Halbwachs, 1980, p. 78). Certainly, history derives from collecting memory or memories, but according to Halbawachs, history is essentially regulated and presented with certain principles, which ultimately differs from all memory. As Halbwachs noticed, "General history starts only when tradition ends, and the social memory is fading or breaking up" (Halbwachs, 1980, p. 78). The justification of this thesis basically consists of two reasons. The first reason is the continuity of memory and the discontinuity of history; there is an impression that people, traditions, and relationships change radically in every historical period, whereas such changes are almost invisible within the living memory. From an epistemological point of view, this observation reminds a well-known narrativist thesis that nothing corresponds to the narratives in reality. The other reason is the limitation of memory and the universalistic ambitions of history; there is no universal memory, as collective memories are numerous, and history tends to be universal. Besides, essential and inessential properties are undistinguished in the memory, while history presents itself as a necessary and definite substance. On the one hand, this means that the event cannot become history as long as are alive the generations who have witnessed that event, because emotional experiences will not give a chance to present a linguistic narrative. But on the other hand, it means that from a historical point of view the legitimacy of memories will lead to political manipulations. This part of the problem has been touched upon in more detail by Pierre Nora, continuing the constructivist approach from Halbwachs, but, indeed, also proofreading it.

Nora is, first of all, well-known with the idea of 'lieux de mémoire' (memory locations). 
By lieux de mémoire, he certainly does not refer to the topographical locations, but rather socalled crystallized memory in the broadest sense: flag, calendar, archive, museum, library and so on. Moreover, "they are lieux in three senses of the word - material, symbolic, and functional" (Nora, 1989, p. 18-19). Nora begins with the idea of the difference between memory and history and adds that they are now radically opposed. "Memory is life, borne by living societies founded in its name. ... History, on the other hand, is the reconstruction, always problematic and incomplete, of what is no longer. Memory is a perpetually actual phenomenon, a bond tying us to the eternal present; history is a representation of the past", - writes Nora (Nora, 1989, p. 8). However, they are most significantly opposed at the level of their bearers: "there are as many memories as there are groups... History, on the other hand, belongs to everyone and to no one" (Nora, 1989, p. 9). (It should be noted that often the concept of seemingly neutrality of history becomes the subject of political discourse; history is, in any case, presented on behalf of a group and viewpoint, in fact, questioning the memories of others).

According to Nora, history-memory has been lost due to the breakdown between memory and history. Considering the contradictory tendency of language and experience, Nora notes that "we speak so much of memory because there is so little of it left" (Nora, 1989, p. 7). Memory diminishes because the nation is lost as the main bearer of the collective memory, yielding to the impersonal society. Essentially, it is due to the nationality that the memory aspiration maintains its virtue, "the memory-nation was thus the last incarnation of the unification of memory and history" (Nora, 1989, p. 11). The society which tends to ruin the very traditional, no longer perceives memory as a prayer, believing only in archives. Memory is materialized (transforming into a location), the sacred cleans its tracks from the memory space, the archives devour life, history captures memory. And in this environment, talking about memory, therefore, you talk about history. All this happens because of the 'acceleration of history,' which destroys all historical metanarratives and, hence, the national identity. And in this case a historian has nothing else to do than to propose lieux de mémoire which seem to be aimed at eliminating the gap between memory and history. Nora who is a chairman of the international association Freedom for History, protests against the law deriving from the French constitution, that the President has the right to interfere with the solution of historical problems, as a result of which, in fact, the memory extends extensively from history. In this point, the political context of the problem of relationship between history and memory is discovered. Every historical and political subject, by ignoring others memories, tries to make a 'universal' history and impose it on the public.

However, such an aggressive campaign of history reveals the corresponding rebellion, as a number of questions remain unanswered. In other words, "mere contrasting of the memory and the history cannot introduce the immense range of the history in a comprehensive manner. To perceive the relationship between the memory and the history means somehow to reveal both their difference and contrast, and especially the prospects of comparative dialogue" (Hovhannisyan, 2014, p. 76). These prospects are thoroughly analyzed by Jan and Aleida Assmanns. Jan Assmann recognizing that memory is manifested in communication nevertheless describes Halbwachs's approach as an extreme one and sug- 
gests to consider the problem not only from the logical point of view but also in the historical context (see Assmann, 1988). Historically, the relationship between memory and history can be presented in three stages: the identity between history and memory, the polarization between history and memory, and the interaction between history and memory (see, Assmann, 2008, p. 57).

For a long time, since Ancient Greece history, writing has merely meant to fix the memory. The goddess Mnemosyne was the mother of the all Muses which embodied the universal memory and thus the whole past from which the present is emerged both in material and poetic world. And it is no coincidence that the knowledge in Plato's philosophy was identical to recollection or memory. To be a historian in Greek culture means to remember people, to be poet means to remember the gods. And this was also the reason why the poet was more important than the historian there. In the early modern times, though, the Cartesian cogito was separated from memory and history and turned into a purely logical structure. Nevertheless, history and memory remained together, although in the shade. The polarization between history and memory began with the emergence of historism when the historical consciousness in Europe became more material in the form of faculties, chairs, and sciences. The historiography demanded rhetorical, stylistic, logical, and other methods that elevated it from the private and indefinite memory. And historical narratives had almost nothing in common with the memory. The latter both intellectually and psychologically was criticized either as a result of imagination (Breton), or an unconscious choice (Freud), or a hopeless shelter of the past.

Nevertheless, the polarisation between history and memory had to shrink. Otherwise the solution to some problems would have been postponed forever. This refers to the history in the postmodern condition and the possibility of thinking the identity, particularly traumatic identity. Lyotard has already shown that postmodern is an incredulity toward metanarratives (see Lyotard, 1984, p. xxiv) or the end of the Big Story. And, apparently, the memory is as much unreliable as the history. Moreover, in the series of postmodern deconstructions the history is inevitably ahead of the memory since the latter has individual bearers, is more subjective and vital.

An even more powerful incentive for the interaction between history and memory is the identity crisis, for the memory, obviously, is an essential element of what is now called collective identity. Generally, when we speak about identity, particularly about national identity, we should take into account two different principles: the first is ethnos, geographical location, language, traditions, etc., the second is the national memory which creates myths. In the contemporary world the former are either vanishing or ultimately unable to propose an operational program about national identity. The myths created by the collective memory are only able to convert the narratives of the past into 'icons' and to ensure the continuity of the collectivity.

Since the trauma usually has greater capability to ensure a collectivity, so the problem of the relationship between history and memory becomes more urgent in the context of the trauma. One may say that "for some scholars interested in memory as a metahistorical category, 'trauma' is the key to authentic forms of memory, and memories shaped by trauma are the most likely to subvert totalizing varieties of historicism" (Klein, 2000, p. 138); and the trauma memories are the most authentic. In publications dedicated to the trauma, the genocide has become the subject of many investigations, sure- 
ly, in the form of Holocaust. By the way, Nora has even developed a conception of hierarchy of genocides where the Holocaust and the Armenian Genocide (Eghern) are contrasted (see Hovhannisyan, 2014). The memory passed through the Genocide tries to turn into a history that will bridge the past and the present, for the universal memory "is the quality of the male genius" (Weininger, 2005, p. 106). One of the best examples of making a history by witnesses and survivors is perhaps a French documentary film Shoah (1985) by Claude Lanzmann which lasts nine hours. From the standpoint of identity, the influence of the Genocide is the loss of own grounds, so the problem is the restoration of those grounds. And it is here the memory-history process tends to fill that decayed gap, it is here that memory and history are united; the memory wants more or less substantial reasoning, and history tries to extract vitality from memories.

\section{REFERENCES}

Assmann, A. (2008, Spring). Transformations between History and Memory. Social Research, 75(1), 49-72.
Assmann, J. (1988). Kollektives Gedächtnis und kulturelle Identität. Kultur und Gedächtnis, 9-19. (J. Assmann und T. Hölscher, hrsg.). Frankfurt: Suhrkamp.

Halbwachs, M. (1980). The Collective Memory. New York: Harper \& Row.

Hovhannisyan, S. (2014). Memory and History. The Problem of Hierarchy of Genocides in Pierre Nora's Theory. Yerevan: Antares.

Klein, K. L. (2000, Winter). On the Emergence of Memory in Historical Discourse. Representations, 69, 127-150.

Lyotard, J.-F. (1984). The Postmodern Condition: A Report on Knowledge. (G. Bennington and B. Massumi, Trans.) University of Minnesota Press.

Nora, P. (1989, Spring). Between Memory and History: Les Lieux de Mémoire. Representations, 26, Special Issue: Memory and Counter-Memory, 7-24.

Sontag, S. (2003). Regarding the Pain of Others. New York: Farrar, Straus and Giroux.

Weininger, O. (2005). Sex and Character. Indiana University Press. 